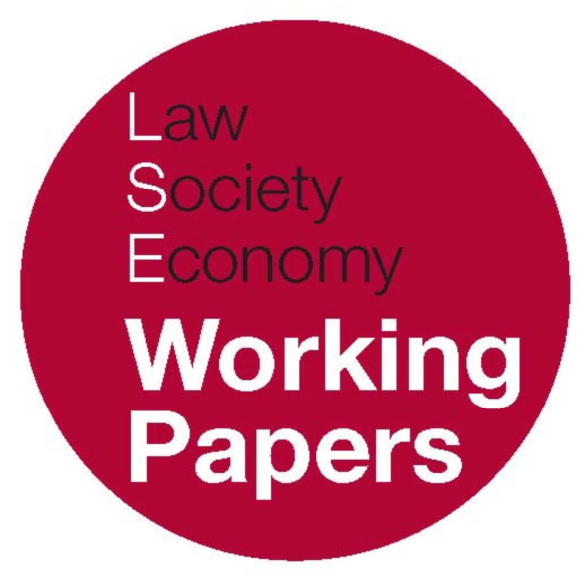

\title{
The Constitution of the Conflict of Laws
}

\author{
Jacco Bomhoff
}

LSE Law, Society and Economy Working Papers 4/2014

London School of Economics and Political Science

Law Department

This paper can be downloaded without charge from LSE Law, Society and Economy Working Papers at: www.lse.ac.uk/collections/law/wps/wps.htm and the Social Sciences Research Network electronic library at: http://ssrn.com/abstract $=2376171$.

(C) Jacco Bomhoff. Users may download and/or print one copy to facilitate their private study or for non-commercial research. Users may not engage in further distribution of this material or use it for any profit-making activities or any other form of commercial gain. 


\title{
The Constitution of the Conflict of Laws
}

\author{
Jacco Bomhoff*
}

\begin{abstract}
Private international law doctrines are often portrayed as natural, largely immutable, boundaries on local public agency in a transnational private world. Challenging this problematic conception requires a reimagining of the field, not only as a species of public law or an instrument of governance, but as a constitutional phenomenon. This paper investigates what such a 'constitution of the conflict of laws' could look like. Two features are given special emphasis. First: the idea of the conflict of laws as an independent source of constitutionalist normativity, rather than as a mere passive receptacle for constraints imposed by classical, liberal, constitutional law. And second: the possibility of a local, 'outward-looking' form of conflicts constitutionalism to complement more familiar, inwardly focused, federalist conceptions.
\end{abstract}

\footnotetext{
* Department of Law, London School of Economics and Political Science. I am grateful to Stéphanie Francq, Ugljesa Grusic, Christian Joerges, Trevor Hartley and Jan Kleinheisterkamp for their comments. Thanks also to Horatia Muir Watt and Ralf Michaels, and participants at seminars at Sciences-Po Paris and Duke University Law School, where earlier drafts were presented. A version of this paper is forthcoming in Horatia Muir Watt (ed.), Private International LaW as Global Governance (Oxford: Oxford University Press, 2014). The usual disclaimer applies.
} 


\section{INTRODUCTION}

The project for this paper is to bring constitutionalist concerns to bear on the question of the relationship between private international law and global governance. A turn to constitutionalism is a familiar - and by no means unproblematic - move in times of crises of legitimacy. Against such a background, appealing to constitutionalist ideas in relation to contemporary transnational private law emerges as an attempt to restoratively invoke some form of 'the public' in the face of increasing threats of private hegemony. ${ }^{1}$ Alternatives for such a move might include turns to public international law, to the more managerial and technocratic forms of global administrative law and global governance, or to hybrid forms like 'transnational public policy'. It is not immediately obvious, however, what invoking constitutionalism, specifically, could mean in relation to a highly fragmented, pluralist, transnational private sphere. What, more in particular, might 'the constitutional' mean in relation to 'the private international', and viceversa?

In some of its guises, that question is hardly new. There is a voluminous literature on the influence of constitutional law on private international law, or the conflict of laws, notably in federal systems, like the United States, or in the semifederal setting of the European Union. But these familiar connections leave a whole range of other questions unexplored. Does private international law, as a legal field, have a constitution? Could private international law be a constitution? And: Can we conceive of a distinctive form of conflict-of-laws constitutionalism? It is this less familiar range of questions that is addressed in this this paper.

I advance two specific arguments. One relates to the question of whether private international law has a constitution - and a distinctive constitutionalism to go with it. This argument starts with conventional understandings of the relationship between constitutional law and private international law. I suggest that these conceptions are curiously limited in that they tend to focus merely on the commands and constraints classical constitutional law imposes on the conflict of laws. That approach, however, leaves unexamined the idea of the conflict of laws as an independent source of constitutionalist normativity, to complement or correct classical liberal - state - constitutionalism. I also suggest, though only in outline in the context of this paper, that inspiration for the content of such a private international constitutionalism could be sought by way of analogy with conceptions of 'sectorial' constitutionalisms, like an environmental- or a labour constitutionalism.

\footnotetext{
${ }^{1}$ This sphere encompasses the traditional legal fields of private international law - in conjunction with elements of domestic- and uniform substantive private law - as well as those of international commercial arbitration, of the area commonly designated as 'transnational private regulation', and at least parts of international investment arbitration. The terms private international law and conflict of laws are used here as synonyms.
} 
The other argument relates to the question of whether private international law could be a constitution - or part of a constitution - for the transnational private sphere. Here again, I start with classic accounts of the constitutional law / conflict of laws relationship and note that they tend to emphasize the role conflicts doctrines play within federal systems. Conflict of laws, on these views, emerges as an application of federalist principles with regard to private law. In this paper, by contrast, I try to show how this inwardly focused federalist conception needs to be complemented by an outward-looking, local conflicts constitutionalism. The vocation of such a local conflicts constitutionalism could be to strengthen private international law as a site for deliberation and contestation over the identity and boundaries of polities. Such strengthening, I argue, is an urgent project for a field that has long been seen as imposing natural constraints on local public agency in a transnational private world.

The paper is structured as follows. Section II discusses the way in which private international doctrine naturalizes limits to local public agency, using the example of early attempts to regulate road safety. The idea of the constitutional, in this Section, emerges first as the idea of the constituted: that which is not natural and inevitable, but subject to choice and innovation. Section III presents a brief overview of conventional ways of mapping the relationship between private international law and constitutional law, as a common background to the two main arguments set out above. Section IV takes up the topic of private international law as a constitution. The constitution of the conflict of laws, in this sense, is presented as a hybrid phenomenon, operating on both global and local levels, simultaneously constituting a transnational sphere of private autonomy and multiple local spheres of public agency. Sections V and VI then discuss the idea of a constitutionalism for the conflict of laws. The first of these Sections makes the case for a local, as opposed to a federal, form of constitutionalism, while the second turns to sectorial analogies as sources of inspiration for the substantive content of a conflicts constitutionalism. Section VII concludes.

\section{THE NATURAL AND THE CONSTITUTIONAL}

The assertion that private international law doctrine naturalizes the boundaries of what is possible in the regulation of private law relations across borders relies as much on an understanding of a pervasive disciplinary mood as it does on legal technicalities. ${ }^{2}$ It is to heighten sensitivity to this mood, and to show the possibility of alternatives, that this Section begins with this brief historical account of disruptive technological advance and legal response.

Just over a century ago, a visionary entrepreneur packaged a radically new form of individual freedom into 'the simplest designs that modern engineering

\footnotetext{
2 One of the effects of this mood is precisely to present such questions of possibility and impossibility as - mere - juridical technicalities.
} 
[could] devise'. Within a matter of years, these freedom machines had become an 'almost necessary instrument in modern life'. They had transformed traditional notions of space, of the home, of romance even. And they were well on their way to killing over 20.000 people in the United States a year, injuring many tens of thousands more. ${ }^{3}$

This was the landscape American state legislatures were confronted with by the early 1920s, when they sought to regulate the use of cars on their roads. Many of these early laws were challenged, and upheld, in the courts. ${ }^{4}$ One problem, though, was especially difficult to solve: that of protecting persons and property within a state against injuries caused by transient non-residents. This was, as one contemporary writer helpfully explained, 'due to the speed of the automobile, which not only tends to cause accidents but also affords the operator an opportunity to escape from the place in which the accident happened'. ${ }^{5}$ A Supreme Court judgment of the time lists the obstacles to simple civil damages actions, thrown up by the governing legal framework:

The process of a court in one state cannot run into another and summon a party there domiciled to respond to proceedings against him. Notice sent outside the state to a non-resident is unavailing to give jurisdiction in an action against him personally for money recovery. There must be actual service within the state of notice upon him or upon someone authorized to accept service for him. A personal judgment rendered against a nonresident [sic], who has neither been served with process nor appeared in the suit, is without validity. The mere transaction of business in a state by nonresident natural persons does not imply consent to be bound by the process of its courts. ${ }^{6}$

Nearly a hundred years later, while many of the technical doctrines have changed, this still sounds surprisingly familiar as a description of current thinking about regulating private law relations beyond state borders. Then, by the early 1920s, the US Supreme Court had been insisting for around fifty years on a framework of strict territoriality and state sovereignty that prevented courts from taking jurisdiction in civil damages cases over defendants not served within the forum. ${ }^{7}$ With out-of-state service unthinkable, hapless injured citizens, it seemed, would simply have to hope that their alleged tortfeasors would one day drive by again. Modern businesses, much like these early drivers, also routinely manage to escape the reach of local regulations. One major reason for this is the fact that the

${ }^{3}$ Cf. Ford, My Life and Work (1924), p. 73; Scott, Jurisdiction over Nonresident Motorists, 39 Harv. L. ReV. 563, 565 (1925).

${ }^{4}$ See e.g. USSC Packard v. Banton, 264 U.S. 140 (1924) (New York statute requiring posting of security or insurance to pay for damages in case of death or injury not so burdensome as to amount to a confiscation).

${ }^{5}$ Scott (1925), p. 565.

${ }^{6}$ USSC Hess v. Pawloski, 274 U.S. 352, 355 (1927) (emphases added).

7 The classic authority is USSC Penoyer v. Neff, 95 U.S. 714 (1878). 
principle of party autonomy - in jurisdiction, choice of law, and commercial arbitration - has for at least the past half century enjoyed essentially the same unquestioned status occupied earlier, and still, by territoriality and sovereignty. ${ }^{8}$

At first sight, then, these are two equally defeatist accounts of limits to the capacity of local communities to regulate hazardous trans-local private activity. In both, the idea of such local regulation emerges not merely as something that might be difficult to achieve, but rather as something that, in juridical terms, simply cannot be done. The earlier story, however, comes with a twist. In the face of the legal constraints listed above, several state legislatures adopted innovative statutory provisions to enable their courts to take jurisdiction over out-of-state drivers. Use of a state's highways by a non-resident, these new rules stipulated, would simply be deemed equivalent to the appointment of a state official - the registrar of motor vehicles - as agent on whom process could be served within the jurisdiction. ${ }^{9}$ In a 1927 decision, Hess v. Pawloski, the US Supreme Court held that these provisions on service did not violate the Due Process clause of the fourteenth amendment to the US Constitution. Motor vehicles were dangerous machines, the Court noted, and states could make and enforce 'regulations reasonably calculated to promote care on the part of all, residents and nonresidents alike', who used their highways. Even though these statutes implied consent in a rather spectacularly fictitious fashion, and even though they treated non-resident defendants less favourably than residents, they had to be seen as such reasonable and necessary measures. ${ }^{10}$

Contemporary transnational private law shows very little of the assertive spirit on such remarkable display in Hess v. Pawloski and in the statutes it upheld. The dominant mood in fields like private international law and international commercial arbitration, and in theorizing on modern forms of lex mercatoria, rather embraces the idea of stringent limits to state authority in a post-state world. That mood is sustained both by sociological accounts of the overburdening of state law and politics under conditions of extreme, globalized functional differentiation, and by law-and-economics inspired attacks on the inefficiencies of public regulation. ${ }^{11}$

\footnotetext{
${ }^{8}$ See e.g. Rühl, Party Autonomy in the Private International Law of Contracts, in Gottschalk, Michaels, Rühl, von Hein (eds.), Conflict of Laws in a Globalized World (Cambridge University Press, 2007), p. 158 (party autonomy 'not seriously called into question on either side of the Atlantic'); Perez, Normative Creativity and Global Legal Pluralism: Reflections on the Democratic Critique of Transnational Law, 10 IND. J. GLOB. LEG. STUD. 25, 41 (2003) (New York 1958 Arbitration Convention as the basis for a 'space of noninterference'); Muir Watt, Private International Law beyond the Schism, 2 TranSNAT'L Legal TheOrY 347 (2011); Muir Watt, Le principe d'autonomie entre libéralisme et néolibéralisme, in Fallon, Lagarde, PoillotPeruzzetto (eds), La Matière Civile et commerciale, socle d’un code Européen de droit INTERNATIONAL PRIVÉ? (Dalloz, 2009).

${ }^{9}$ See e.g. 90 , General Laws of Massachusetts, as amended by Stat. 1923 , c. $431, \S 2$.

10274 U.S. 352, 356.

11 See e.g. Sand, Polycontextuality as an Alternative to Constitutionalism, in Joerges, Sand, Teubner, Transnational Governance and Constitutionalism (Hart, 2004), p. 64; Teubner, CONSTITUTIONAL Fragments: SOCIETAL CONSTitutionalism AND Globalization (Oxford University Press, 2012); Walker, The Idea of Constitutional Pluralism, 65 MoD. L. REv. 317, 320 (2002). The politics of these accounts tend to be diametrical opposites. See e.g. Zumbansen, Defining the Space of Transnational Law: Legal Theory, Global Governance, and Legal Pluralism, 21 Transnat'L L. \& ConTEMP. ProBs. 305, 310 (2012).
} 
In this environment, private international law doctrines in particular play a crucial, but often unnoticed, role in facilitating an understanding of state regulation as constrained by natural boundaries. ${ }^{12}$ The literature on transnational private regulation, to the extent that it sees local public law as significant at all, regularly brings this out very clearly. In a typical account, state courts have enforcement powers that are geographically limited'. The state's domestic regulatory competencies 'do not extend readily into the transnational realm', and domestic courts cannot easily intervene 'unless a link under private international law grants jurisdiction to them'. ${ }^{13}$ The point is not that such statements are inaccurate, and that these 'jurisdictional obstacles' somehow do not exist. The argument is rather that in these accounts such 'obstacles' are naturalized. While virtually all other elements of the legal process are seen as potential objects of, and instruments for, regulatory innovation, the required link under private international law' commonly appears in this literature as a given. Limits on jurisdiction, almost boundless party autonomy, strict obligations to enforce arbitral awards, the near-impossibility to give effect to even the most important elements of the legislation of another country (if that country does not supply the otherwise applicable law); all of these are simply part of the world of transnational law and litigation as it is and always will be.

My argument is this: If we want to challenge these narrow conceptions of what is normal, exceptional, and impossible in contemporary private international law, we will need to do more than merely re-imagine the field as an object and instrument of regulation or governance, as a species of public law, or as a forum for politics. ${ }^{14}$ Such a challenge demands, in addition, an understanding of private international law as a constitutional phenomenon. This argument is based in part on what Gunther Teubner has recently called the fallacy of the 'constitutional emptiness of the transnational'. 15 Numerous social subsystems in the transnational sphere, Teubner notes, already have constitutions, at least in the sociological sense of reflexive mechanisms by which they secure their own autonomy. But what is striking about these 'constitutions of global functional regimes', and in particular about the constitutions of global markets, is how in recent decades they have exclusively pursued - and have been allowed to pursue - the one-sided aim of achieving autonomy for their social subsystem. ${ }^{16}$ Along the way, Teubner argues,

\footnotetext{
12 Muir Watt (2012), p. 382; Bomhoff \& Meuwese, The Meta-Regulation of Transnational Private Regulation, 38 JOURNAL OF L. \& SOC. 138 (2011).

${ }_{13}$ Verbruggen, Gorillas in the closet? Public and private actors in the enforcement of transnational private regulation, 7 REGULATION \& GOVERNANCE (2013), p. 512 (internal references omitted).

14 See, e.g., Muir Watt (2012) (on politics); Mills, The Confluence of Public and Private International LAW (Cambridge University Press, 2009) (on the public/private divide); Bomhoff \& Meuwese (2011) (on regulatory perspectives).

15 Teubner (2012), p. 7. The argument in this paper does not, I think, depend on acceptance of all elements of Teubner's theory of societal constitutionalism.

16 Teubner (2012), pp. 76-77.
} 
attention to constitutionalism's crucial second function, of (self)-limitation, has been lost. ${ }^{17}$

Private international law has so far been largely complicit in this unbalanced quest for transnational autonomy, enabling the creation of informal, private empire that now threatens to overwhelm local agency. ${ }^{18}$ But my central claim in this paper is that this same field, when seen through a constitutionalism lens, also holds untapped potential for recalibration. Such a rebalancing would of course have to be more than simply a more aggressive approach to unilateral, local, public regulation of transnational private activity. ${ }^{19}$ On this point, too, Hess $v$. Pawlosk $i$ is instructive. There, the extension of jurisdiction went hand in hand with careful attention to due process concerns and questions of equal treatment. ${ }^{20}$ Along similar lines, the vocation of a constitution of the conflict of laws could be to enhance the capacities of private international law as a site for deliberation and contestation over the character and boundaries of the identities and responsibilities of polities. ${ }^{21}$ As Karen Knop has argued, much of this turns on merely excavating lines of thought and doctrine already present in private international law. The field exhibits striking histories of, both, an 'actually existing cosmopolitanism', 22 and, as in Hess v. Pawloski, actually existing local assertiveness.

\section{CONSTITUTIONAL AND PRIVATE INTERNATIONAL: MAPPING RELATIONSHIPS}

Conventional understandings of the relationship between constitutional law and private international law run in two main directions. At first sight at least, these are strikingly different.

\footnotetext{
${ }^{17}$ Ibid., calling this a process of worldwide 'neo-liberal' constitutionalization.

18 Muir Watt (2012), pp. 381-382 ('It is to a large extent through the denials of their private international law that states have been complicit in the development of the informal empire that now threatens to overwhelm them').

${ }^{19}$ Cf. Muir Watt \& Bureau, Droit International Privé (Presses Universitaires de France, 2010), Vol. I, p. 31. Attention to the interests of outsiders to state democratic processes lies at the heart of the invocation of conflict-of-laws methods in the work of Christian Joerges and Florian Rödl. For the claim that unilateral regulation of transnational business is inherent in the concept of the rule of law, see Francq, L'APPLiCABILITE DU DROIT COMMUNAUTAIRE DERIVE AU REGARD DES METHODES DU DROIT INTERNATIONAL PRIVE (Bruylant/LGDJ, 2005), pp. 577-640.

20 The court found that 'literal and precise equality' between residents and non-resident drivers was not necessary or even possible. It was enough that the statutes did not impose any 'hostile discrimination' and that they safeguarded the rights of defense by requiring subsequent notice at the defendant's home address.

21 See, e.g., Wai, In the Name of the International: The Supreme Court of Canada and the Internationalist Transformation of Canadian Private International Law, 39 CAN. Y.B. INT'L L. 117, 122 (2001) (aiming for a 'richer discourse about international public policy in the development of [...] private international law', in the form of 'an approach that rejects both naïve internationalism and naïve anti-internationalism').

22 Knop, Citizenship, Public and Private, 71 Law \& Contemp. Probs. 309, 311, 341 (2008) (emphasis added).
} 
On the one hand, constitutional law and private international law are natural allies in many federal systems, with the United States, Canada, and Australia as the best-known examples. But that immediate intuitive connection comes with some complications. For one, the ways in which the two fields are seen as related show significant differences, not only between these systems but also over time. The very familiarity of the connection may also hinder the examination of questions that are not part of any local conflict-of-laws / constitutional law canon. ${ }^{23}$ Finally, and related, it is worth noting that, from among these examples, both Canadian and Australian jurisprudence have been influenced by the work of Albert Venn Dicey, in both constitutional law and conflict of laws. Dicey's conception of the nature of sovereignty, and his strict separation between public and private law, as Campbell McLachlan has recently noted, have left much of the common law world 'relatively underprepared to adopt a coherent approach to the extraterritorial rights and duties of states in the present century'. ${ }^{24}$ And it is precisely such questions on extraterritorial rights and duties that a conflicts constitutionalism in the sense intended here would have to address.

On the other hand, the private international / constitutional law connection is radically at odds with some basic tenets of private international law in the European continental tradition shaped largely by Savigny. But here too, the picture is more complicated. In part, this is because EU law and ECHR human rights law have wrought profound changes in European private international law over the past three decades. Those changes have reinforced the field's public dimensions, although, troublingly, not necessarily also its constitutional foundations. European private international law, then, is in the midst of a longer process of transformation, with potentially profound consequences.

Taking a step back from these two contingent institutional and historical settings, the relationship between constitutional law and private international law can be conceived from at least three more abstract basic angles.

On a first view, private international law is simply one among many fields of law impacted by constitutional norms. This, to a large extent, is the classic topic of the constitution and private international law. The constitutional norms in question could be those of a local unit - a state or province, for example - or, more typically, those of an overarching federal, or semi-federal, structure. Among the familiar instances of this type of connection are the debates in the US in the early 1930s, when it appeared to some as if the conflict of laws was about to become a

\footnotetext{
${ }^{23}$ Cf. Trachtman, The Constitutions of the WTO, 17 Eur. J. INT'L L. 623 (2006); Henkin, The Constitution as Compact and as Conscience: Individual Rights Abroad and at our Gates, 27 WM. \& MARY L. REV. 11, 11 (1985) (referring to questions on the rights of aliens, on the status of immigrants, and on 'the applicability of the Constitution to persons outside the United States', as lying away from 'the paths commonly trodden by students of the United States Constitution').

${ }^{24}$ McLachlan, The Allocative Function of Foreign Relations Law, BRITISH Y.B. INT’L L. 349, 356 (2013). US constitutional jurisprudence shows a similar inward focus, traceable at least in part to textual silence in the Federal Constitution and in the Bill of Rights in relation to the rights of outsiders and the extraterritorial projection of governmental authority.
} 
mere 'branch of constitutional law'. ${ }^{25}$ Another example would be the programmatic statement by the Supreme Court of Canada, in Morguard v. De Savoye, that 'the rules of $[\ldots]$ private international law $[\ldots]$ must be shaped to conform to the federal structure of the constitution'. ${ }^{26}$ From a conflicts perspective, this first angle is modest in that it portrays private international law as a mostly passive receptacle - a mere tool - for constitutional demands. ${ }^{27}$

A second, and from a conflicts perspective more ambitious, familiar conception sees private international law as actively fulfilling constitutional functions. This is the idea of private international law as constitutional law. That idea has found recognition, for example, in the Supreme Court of Canada's vision of the 'confluence of private international law and constitutional law'. Under this label, the Court affirmed its view that 'coordination in the face of diversity is a common function of both public and private international law [...] [and] also one of the major objectives of the division of powers $[\ldots]$ in a federation'. ${ }^{28}$

On a third view, finally, the relationship between the two fields is reversed. From this angle, it is constitutional law that emerges as a form of conflict of laws. This type of approach most frequently takes up the form of an analogy, as, for example, in Ralf Michaels' claim that ' $[\mathrm{t}] \mathrm{he}$ country-of-origin principle in EU law is best understood by analogising it to the vested-rights theory in private international law'.29 Other influential examples would include Christian Joerges' conception of EU law as a form of 'conflicts law', inspired by American conflictof-laws theories, and Gunther Teubner and Andreas Fischer-Lescano's analysis of 'regime collisions', elaborated more recently by Gunther Teubner in the form of a 'global constitutional conflict of laws'. ${ }^{30}$

These, then, are three abstract conceptions of normative hierarchy: of the conflict of laws as a mere tool for the effectuation of constitutional demands, of conflict of laws and constitutional law as co-equal sources of constitutionalist normativity, and of the conflict of laws as itself a source of inspiration or template for constitutionalism. These three views cannot, of course, be kept strictly separate in practice. Many further forms of combination of private international law and constitutional law are conceivable. ${ }^{31}$ And it would in any event be an illusion to

\footnotetext{
${ }^{25}$ See, e.g., Leflar, Constitutional Limits on Free Choice of Law, 28 LAw \& CONTEMP. Probs. 706, 706 (1963). 26 [1990] 3 SCR 1077, 1101.

27 See also, e.g., Mills (2009), p. 204 (two-step model for the relationship between choice of law and EU law, in which EU law operates in a "separate "second stage" to affect the application or modify the content of the applicable law').

${ }^{28}$ SCC Hunt .v TeN plc, [1993] 4 SCR 289, 296.

${ }^{29}$ Michaels, EU Law as Private International Law? Reconceptualising the Country-of-Origin Principle as Vested-Rights Theory, 2 J. PRIV. INT'L L. 195, 199 (2006).

30 See, e.g., Joerges, The Idea of a Three-Dimensional Conflicts Law as Constitutional Form, in Joerges \& Petersmann, Constitutionalism, Multilevel Trade Governance and International Economic LAW (2nd ed., Hart, 2011), p. 413; Teubner \& Fischer-Lescano, Regime-Collisions: The Vain Search for Legal Unity in the Fragmentation of Global Law, 25 Mich. J. InT'L L. 999 (2004); Teubner (2012), p. 13. These approaches are in many ways very different, but nothing turns on these differences here.

${ }^{31}$ See, e.g., Fawcett, The Impact of Article 6(1) of the ECHR on Private International Law, 56 INT'L \& COMP. L.Q. 1, 24, 36 (2007) (using human rights law to 'cast light on the meaning' of key PIL concepts, or a two-stage, 'hybrid' approach of using human rights law to identify human rights problems, and PIL
} 
think that it will always be possible, in judicial or scholarly legal reasoning, to identify exactly from within which field of law any particular normative argument originates. ${ }^{32}$ The point of this typology is merely this: to show how in the relationship between constitutional and private international legal thought, both fields - and not just the constitutional - can be a source of a type of normativity that, as will be argued below, is best seen as a form of constitutionalism. The content, or even the presence, of this constitutionalism is rarely made explicit. But especially in the second and third scenarios outlined above, where private international law plays an independent constitutional role, or is taken to inspire constitutional norms, some form of constitutionalist normativity from within private international law must be at work, even if it commonly remains unacknowledged. A more practical way of putting this point is to say that merely studying legal materials that come under the traditional heading of 'constitutional law' does not give a complete picture of what constitutionalism, even in its classical sense, is about - private international law is part of the constitutional framework that allocates and limits public authority under law. But if that is true, then private international law has to be seen as itself also the source of a type of normativity best seen as constitutionalist in character.

One example of how difficult it often is to unearth this particular kind of normativity can be found in Lord Bingham's speech in the English case of Lubbe $v$. Cape. This case concerned a very large number of personal injury claims against an English company engaged in asbestos mining in South Africa brought in England, by former workers at the mine. It was common ground before the English court that the claimants would not be able to have their cases heard in the South African courts, as it would be prohibitively expensive to proceed without legal aid, which would not be available there. Such financial aid could, however, be obtained for trial in England. At issue was the question of whether, and if so how, this fact should play a role in the English court's forum non conveniens analysis. Having reached the conclusion that the case should proceed in England, Lord Bingham summed up his position on the relationship between human rights law and private international law by stating ' $\mathrm{I}$ do not think article 6 [of the ECHR] supports any conclusion which is not already reached on application of [the conventional, English conflict of laws] Spiliada principles'.33 Putting private international law norms 'first' in this way, as James Fawcett has noted, 'gives the impression that

doctrines to solve them); Martin, Constitutional Limitations on Choice of Law 61 CoRNELL L. REv. 185, 185 (1976) (constitutional limits on choice of law in the US as '[a] discrete body of Supreme Court case law that has been generally ignored by constitutional law experts').

32 On the relationship between private international law and constitutional law, see also more recently SCC Club Resorts Ltd. v. Van Breda, 2012 SCC 17, par. $22 \mathrm{ff}$ (search for 'conflicts rules that would accord with the constitutional imperative' - closer to the first scenario in the typology developed here - but also noting that the 'real and substantial connection test' 'was born as a general organizing principle of the conflict of laws. Its constitutional dimension appeared only later' - which is closer to the second scenario).

${ }^{33}$ Cited in Fawcett (2007), p. 10. 
these rules deal with the human rights concern'. ${ }^{34}$ If that impression is right - and Lord Bingham certainly seemed to think it was right - then the idea that private international law does indeed 'deal with' human rights concerns must imply some broader underlying normative vision, proper to the field itself, speaking to individual rights and state responsibilities. In Lubbe v. Cape, for example, that vision would have to 'deal with' the responsibility to provide a venue for tort litigation, for at least certain types of personal injury cases, in at least some types of cases where alternative venues are not available. It is these aspirations and commitments located within private international law itself that will be referred to here as conflicts constitutionalism.

\section{THE CONFLICT OF LAWS AS A CONSTITUTION}

One meaning of the phrase 'the constitution of the conflict of laws' is the idea of private international law as a constitution. But how are we to imagine such a constitution? What, in particular, would such a conflicts constitution constitute?

This question is perhaps best addressed, at least provisionally, by way of reference to some of the classic oppositions in private international legal thinking, in particular those between local and international, and between public and private. ${ }^{35}$ If the conflict of laws, as a field of law, straddles these basic oppositions then there is every reason to assume that its constitution will do so too. ${ }^{36}$ The constitution of the conflict of laws would then emerge as a hybrid phenomenon. It could be understood, from a first angle, in a top-down sense, as a form of constitutional law on a global level. Pervasive fragmentation and differentiation at this global level, however, would mean that this constitutional law appears as a 'global constitutional conflict of laws': 37 a collection of principles, techniques and vocabularies pertaining to the ordering of regulatory authority and responsibility in a global or regional setting. The constitution of the conflict of laws, on this first partial view, would then refer to that part of this constitutional conflict of laws that deals predominantly with private law relations. From a second, bottom-up, point of view, the constitution of the conflict of laws could refer to that part of any local - state, federal or regional - constitutional law having any bearing on private law relations that cross the boundaries of that locality. ${ }^{38}$

\footnotetext{
${ }^{34}$ Ibid.

${ }^{35}$ See, among many other examples, Trachtman, Conflict of Laws and Accuracy in the Allocation of Government Responsibility, 26 VANDERBILT J. TRANSNAT'L L. 1 (1994).

${ }^{36}$ Not simply transcend: A constitution of the conflict of laws would constitute these very oppositions to begin with.

${ }^{37}$ Cf. Fischer-Lescano \& Teubner (2004); Teubner (2012), p. 13. This conception could also work at a sub-global, regional level.

38 A useful analogy here is the field of 'foreign relations law' in the US, which operates as a 'sophisticated amalgam of public international law doctrine with the relevant principles of municipal constitutional law'. See McLachlan (2013), p. 373 (emphasis added).
} 
From both these vantage points, what the constitution of the conflict of laws constitutes is, simultaneously, a trans-local sphere for private legal autonomy and numerous local spheres of public authority. In normative terms, this constitution should serve to uphold private autonomy beyond the local, while at the same time preventing this trans-local private sphere from overreaching. And it should function to enable effective local public authority over trans-local matters, while limiting that public authority at the same time. ${ }^{39}$

\section{A CONSTITUTIONALISM FOR THE CONFLICT OF LAWS (I): BEYOND FEDERALISM}

The two perspectives outlined in the previous Section are very different in where they direct their normative gaze, and from what standpoint. One starts at the local, or municipal, level and then looks outward; the other starts from the 'supra-local' to look inward, or downward. Only the second of these two perspectives is commonly associated with constitutionalism. That association is typically formed within federal systems. ${ }^{40}$ Conflicts norms, on this view, operate as secondary rules, or 'meta-norms', of constitutional ordering at this federal level. ${ }^{41}$ They fulfil an architectural function, allocating regulatory authority by curbing local parochialism and imperialism from the centre, and by limiting public authority by way of individual rights. 42

This exclusively 'federal' reading of the relationship between conflict of laws and constitutional law, however, is problematic. Not just on its own terms, but especially also because it misses out on much of the constitutionalist potential within private international law. This alternative reading will be called the 'local' view of conflicts constitutionalism.

A useful way to begin the project of exploring the contours of this local conflicts constitutionalism is to look in some detail at some of the difficulties attending the - more familiar - federal reading. In this respect, the US context furnishes some revealing examples. To begin with, it is not clear why profound differences exist in the degrees to which the major fields of US conflict of laws doctrine are constitutionalized. As is well known, states' jurisdiction to adjudicate is subject to stringent federal constitutional limitations. But modern choice of law is left largely free of such constraints. With regard more specifically to

\footnotetext{
39 This topic is more complex than this preliminary sketch can do justice to. Such a constitution would, for example, also play a role in constituting not just component units or a system, but a 'whole' legal world. See Lindahl, Finding a Place for Freedom, Security and Justice: The European Union's Claim to Territorial Unity, EuR. L. REV. 29 (2004), p. 470.

40 Or on the international level by way of federalism-analogy. See Mills (2009) for discussion.

${ }^{41}$ Mills (2009), p. 124.

42 See, e.g., Baxter, Choice of Law and the Federal System, 16 STAN. L. REV. 1, 34-41 (1946).
} 
constitutional limits on jurisdiction, the Supreme Court's recent decision in Nicastro clearly demonstrates how unsettled some of the most fundamental doctrines remain, even when applied to fairly basic factual scenarios. ${ }^{43}$ In the field of choice of law, the US constitution imposes rather fewer limitations, as mentioned above, but the foundation and justification of these limitations remains highly uncertain. ${ }^{44}$ The meaning and relative significance in particular of the Full Faith and Credit clause and the Due Process clause, is not clear. Supreme Court case law is inconsistent in whether it relies on the one rather than on the other clause, or on both in conjunction. The Justices have at times seen the requirements of the two clauses as identical. ${ }^{45}$ But that view has long been contested in scholarly literature, and in any event sits uneasily with the very different historical backgrounds of the two provisions, ${ }^{46}$ and with the contrast between the types of relationships that they appear to address - between states and individuals (Due Process) and between states inter se (Full Faith and Credit). ${ }^{47}$ Most importantly, the two provisions are at least very different in that Full Faith and Credit cannot apply to extra-federal relations, whereas Due Process can and does. This difference too casts doubts on their purported equivalence in intrafederal cases.

The purpose of this Section is not to rehearse these and other well-known difficulties. The point is merely to suggest that some of them may actually stem in part from the exclusive reliance on a federal vision, to the detriment of any alternative 'local' conception of conflicts constitutionalism. For that project the relationship between Full Faith and Credit and Due Process is particularly interesting. Crucially: in contrast to the Full Faith and Credit clause, the Due Process clause also applies in extra-federal cases - that is: cases involving defendants established outside the US. This difference in scope strongly suggests that some other underlying principles other than mere federal 'architectural' concerns must be at work. Those other principles remain obscured, however,

${ }^{43}$ USSC J. McIntyre Machinery, Ltd. v. Robert Nicastro, 131 S.Ct. 2780 (2011).

${ }^{44}$ See, e.g., Jackson, Full Faith and Credit: The Lanyer's Clause of the Constitution, 45 Colum. L. Rev. 1, 16 (1945) (I think it difficult to point to any field in which the [Supreme] Court has more completely demonstrated or more candidly confessed the lack of guiding standards of a legal character than in trying to determine what choice of law is required by the Constitution').

45 See, e.g., USSC Sun Oil v. Wortman, 486 U.S. 717 (1988). For discussion, see Brilmayer, Goldsmith, O'Hara O'Conor, CONFlict of Laws: CASES AND Materials (6 $6^{\text {th }}$ ed., Wolters Kluwer, 2011), p. 342 ('Wortman must surely make one thing even clearer: that with regard to the issue of whether an adequate nexus exists for the application of local law, the due process and full faith and credit limits are identical'). ${ }^{46}$ See, e.g., the debate between Martin, Constitutional Limitations on Choice of Law, 61 CORNELL L. Rev. 185 (1976), and Kirgis, The Roles of Due Process and Full Faith and Credit in Choice of Law, 62 CoRNELL L. REv. 94 (1976).

${ }^{47}$ Similar confusion reigns in the field of constitutional limitations on jurisdiction, where the status of federalist principles is highly uncertain. See, e.g., USSC Insurance Corp. of Ireland v. Compagnie des Bauxites de Guinee, 456 U.S. 694, 703 ('The restriction on state sovereign power described in World-Wide Volkswagen Corp. [the leading decision in this area] [...], must be seen as ultimately a function of the individual liberty interest preserved by the Due Process Clause. That Clause is the only source of the personal jurisdiction requirement and the Clause itself makes no mention of federalism concerns') (emphases added). Of course, the 'liberty interest' referred to here, still operates as a right granted at the federal level, limiting the authority of local constituent units. But, and this is the crucial point, that changes in extra-federal cases, where the federal level becomes the local, relative to the outside world. 
whenever the two clauses are treated as equivalent. But in addition, even Full Faith and Credit itself - ostensibly the purest expression of the federal role of the conflict of laws - does not appear to be animated solely by federalist concerns. A number of American territories already had very similar statutory provisions even before the Continental Congress. ${ }^{48}$ And the Full Faith and Credit clause as adopted at the Constitutional Convention of 1789 was itself largely derived from a provision in the Articles of Confederation of 1777 (Article IV).49 These earlier provisions too suggest that some other normative concerns, unrelated - or at most weakly related - to principles of federal architecture must also be in play.

One classic article on Full Faith and Credit is especially revealing on this specific issue. Why, Robert Jackson asked in 1945, did the practical impact of this clause seem so limited? His answer: 'Generosity in applying foreign law no doubt has forestalled pursuit of many questions as constitutional ones under the full faith and credit clause'. ${ }^{50}$ This 'generosity' stemmed in part from the fact that the judiciaries of the several states had 'voluntarily accepted as part of their own common law the principles of the Conflict of Laws'. ${ }^{51}$ In these passages, Jackson draws a clear contrast between constitutional questions on the one hand, and common law conflict of laws questions on the other; and between generosity at the state level on one side, and federally imposed constraints on the other. But this distinction leaves some crucial questions unanswered. Where does the courts' vaunted 'generosity' come from? If the application of 'foreign' law by state courts is a constitutional issue when mandated by the Full Faith and Credit clause, then why would this same legal operation, by those same courts, cease to be a constitutional issue when apparently based on their 'generosity'?

A local, outward looking, conception of conflicts constitutionalism would not draw such deep distinctions between the recognition of foreign norms on the basis of 'comity', 'enlightened self-interest' or the 'mutual convenience of nations' on the one hand, ${ }^{52}$ and questions of constitutional obligation on the other. From such a local perspective, all legal relations with the outside world would implicate constitutional concerns.

There clearly are antecedents for this type of local constitutionalist thinking in American private international law thinking - to stay with that example - notably in the work of Joseph Story. '[E]very nation must judge for itself', Story wrote, 'what is its true duty in the administration of justice'. ${ }^{3}$ ' [W] hatever force and obligation

\footnotetext{
${ }^{48}$ Nadelmann, Full Faith and Credit to Judgments and Public Acts: A Historical-Analytical Reappraisal, 56 MicH. L. REV. 33 (1957).

${ }^{49}$ Jackson (1945), pp. $3 \mathrm{ff}$.

${ }^{50}$ Ibid., p. 18.

${ }^{51}$ Ibid., p. 17.

52 Ibid., p. 30. See also Story, Commentaries on the Conflict of Laws (Boston: Hilliard, Gray, 1834), par. 278.

53 Story (1834), par. 34. Story also refers to the more familiar principles of 'mutual interest and utility [...] the inconveniences which would result from a contrary doctrine, and from a sort of moral necessity to do justice, in order that justice may be done to us in return' (par. 35).
} 
the laws of one country have in another, depends solely upon the laws, and municipal regulations of the latter, that is to say, upon its own proper jurisprudence and polity. ${ }^{54}$ And Story's work contains numerous further hints at the importance of some local form of normativity in conflict of laws doctrine of the time. These include: the irrelevance of a party's foreign nationality in commercial law; the idea that domestic substantive constitutional norms, like the protection of private property, would be weakened without adequate conflicts rules to cover cross-border situations; and the need for uniformity with other branches of the law concerning assertions of public authority in situations transcending the boundaries of the polity. 55

Notwithstanding traces like these, the idea of a local, constitutionalist normativity is clearly a marginal one in classical conflicts thinking. In the classical view, state sovereignty, and the attendant exclusion of the foreign, is a constitutional matter. The recognition of foreign norms and interests appears only as an exception - in a sense: as the negation of sovereignty and of the constitutional, and thus merely as an expression of 'comity' or some related, equally unsatisfying, but distinctly not constitutional, principle. Surely, though, if the assertion of local authority is a constitutional matter, then so too is declining to assert that authority, in favour of a foreign norm or decision. ${ }^{56}$ Both assertion and forbearance bear equally on the boundaries of a polity, and on the formation of its identity. A very similar blind spot appears in more modern theories of law beyond states that look to notions of democracy rather than of sovereignty. 'Precisely because democracies enact laws that are supposed to bind those who legitimately authorize them', Seyla Benhabib summarizes these views, 'the scope of democratic legitimacy cannot extend beyond the demos which has circumscribed itself as a people upon a given territory'. ${ }^{57}$ True enough. But while it is widely recognized that within polities, democracy is incomplete without attention to constitutionalist concerns, such as those pertaining to the protection of minorities, the idea that, similarly, it is only reasonable to demand that the external projection of public authority pass through the constraints and exhortations of constitutionalism, is much less prominent.

\footnotetext{
54 Story (1834), par. 21.

55 Story (1834), paras. 281, 4, 21. See also par. 3 ('enlarged sense of national duty'). Reading the irrelevance of foreign nationality in commercial cases, and the relevance of (local) nationality in the pursuit of crimes committed abroad both as manifestations of a local conflicts constitutionalism of course only involves an apparent contradiction.

56 It was his acute awareness of this very point that informed Brainerd Currie's lex-fori solution for cases of true conflict.

57 Benhabib, The Rights of Others: Aliens, Residents, and citizens (Cambridge University Press, 2004), p. 219.
} 


\section{A CONSTITUTIONALISM FOR THE CONFLICT OF LAWS (II): 'SECTORIAL' INSPIRATION}

How best to understand such a local form of conflicts constitutionalism? If we reject both traditional public international law, comity-based, perspectives and the federalist constitutional architecture view, how do we avoid the dangers of, on the one hand, the excessive parochialism of the unquestioned assertion of local law, and on the other, the excessive individual freedom stemming from unregulated party autonomy?

Most of the work in thinking through the content of such a constitutionalism will have to be for a future project. But the agenda would be to try to understand this particular form of normativity as a sectorial constitutionalism - by looking at conflicts constitutionalism as analogous, that is, to, for example, an 'environmental constitutionalism', or to the idea of a 'constitution of labour law'. The comparison with these alternative partial constitutionalisms - in the plural - seems especially useful because they too are simultaneously informed by the classical liberal tradition and envision themselves as corrective of some key aspects of that tradition. As Douglas Kysar writes with reference to environmental constitutionalism, they 'haunt the liberal vision in just the right way'. .58

One of the 'improvements to liberal thinking' that an environmental constitutionalism seeks to accomplish, in Kysar's account, is to force liberalism 'to become more self-conscious of its membership decisions'. 59 ' $[\mathrm{N}]$ o liberal political community should ever view itself as completed', Kysar writes. It should continuously question 'whether its vision of harmonious self-ordering could be made to be more inclusive'. ${ }^{60}$ Liberal thought, as complemented by an environmental constitutionalism,

should not seek final answers to questions of recognition and membership. Instead, it should seek to reinforce collective self-consciousness regarding the need to confront those questions and to remain always dissatisfied with their instant resolution. [...] the most basic of wisdoms remains the implicit reminder that how a society acts in its causal capacity - in geopolitical, intertemporal, and interspecial terms - will determine the content of its identity. ${ }^{61}$

\footnotetext{
${ }^{58}$ Kysar, Global Environmental Constitutionalism: Getting There from Here, 1 TRANSNAT’L ENV. L. 83, 90 (2012). ${ }^{59}$ Ibid., p. 87.

${ }^{60}$ Ibid., p. 90 . Very similar themes figure in writing on labour constitutionalism. The phrase 'labour's constitution' commonly refers to constitutional understandings open to contributions from, and the interests of, constituencies left out of 'ordinary', 'official' constitutional processes. See e.g. Pope, Labor's Constitution of Freedom, 106 YALE L.J. 941, 942 (1997); Forbath, LAW AND THE SHAPING OF THE AMERICAN LABOR MOVEMENT (Harvard University Press, 1991).

${ }^{61}$ Kysar (2012), p. 93. See also, e.g., Koskenniemi, Constitutionalism as Mindset: Reflections on Kantian Themes About International Law and Globalization, 8 THEORETICAL INQ. L. 9 (2007), 35 ('The virtue of constitutionalism in the international world follows from a $[\ldots]$ universalizing focus, allowing extreme
} 
Environmental constitutionalism, in this account, emerges as a particularly developed instance of a more generic understanding of sectorial constitutionalisms: forms of constitutionalist normativity that all, for different societal fields, serve to facilitate the articulation of identity and social autonomy, and to constitutionalize these fields 'by generating environmental responsibilities in the autonomies themselves'. ${ }^{62}$

Private international law, with its wealth of disciplinary experience in managing legal pluralism, would have to be a storehouse of ideas on how to generate these 'environmental responsibilities', and on the relationship between external action and internal identity formation. ${ }^{63} \mathrm{It}$ is, for example, precisely this capacity for 'reflexive orientation', allowing for a 'deep, persistent, and framing awareness of the situatedness of one's claims', that Annelise Riles, Karen Knop and Ralf Michaels have recently unearthed as part of the distinctive normativity of the conflict of laws. ${ }^{64}$ But classical private international law is also importantly incomplete in this respect, for example in the way notions of 'responsibility' are almost entirely absent from its dominant mode of discourse. ${ }^{65}$ The agenda for a sectorial conflicts constitutionalism would be to bring out and reinforce these assorted, but often hidden, experiences and ideas, and to align them with dominant strands of private international law thinking. ${ }^{66}$

\section{CONCLUSION}

One urgent task for a critical conflict-of-laws scholarship is the cultivation of an understanding of private international law norms as very different from any natural, immutable, background landscape against which modern transnational private legal relations play out. Such a move will require conceiving of the field as fulfilling constitutional functions, in the allocation of regulatory authority and responsibility, and the formation and assertion of political and cultural identity. I have argued, however, that in the transnational context, a constitutionalist

\footnotetext{
inequality in the world to be not only shown but also condemned. [...] The use of the constitutional vocabulary $[\ldots]$ transforms individual suffering into an objective wrong that concerns not just the victim, but everyone. If calculation is needed, then "all" must be counted as the cost'.).

62 Teubner (2012), p. 3 (citing Wielsch). 'Environmental' is used here in a generic sense.

${ }^{63}$ This is the idea animating work in the vein of 'constitutional law as private international law', notably that of Christian Joerges, as discussed above in Section II.

${ }^{64}$ Knop, Michaels, Riles, From Multiculturalism to Technique: Feminism, Culture and the Conflict of Laws Style, 64 STAN. L. REV. 589, 635 (2012).

${ }^{65}$ Bomhoff, The Reach of Rights: 'The Foreign' and 'The Private' in Conflict of Laws, State Action, and FundamentalRights Cases with Foreign Elements, 71 LAw \& CONTEMP. ProBs. 39, (2008), pp. 69ff; Francq (2005), pp. 584585, 594-597, 636-637.

66 The idea of conflicts constitutionalism as a 'sectorial' constitutionalism raises many further questions. Private international law is, after all, 'sectorial' in a very different sense than are functional fields of law like environmental law or labour law. Would a conflicts constitutionalism claim application across the board, to all private law relations that cross borders? Or would we have to think of a range of differentiated conflicts constitutionalisms for different societal sectors? It is easy to see how clashes between these different visions might arise.
} 
conception of private international law need not merely refer to principles of federal constitutional architecture. It could also express individual communities' own commitments to their role in the international, constitutional, ordering of law. That, I have suggested, would be the vocation of a local conflicts constitutionalism.

A local conflicts constitutionalism should function to reinforce private international law as a site of contestation and deliberation over questions of authority, responsibility and identity. Ironically, it is precisely this kind of deliberation that a federal-style conflicts constitutionalism tends to inhibit. One of the main dangers in the continuing Europeanization of private international law is that local - that is: predominantly national - debates on the boundaries and responsibilities of polities are stifled, driven out by the as-of-yet rather problematic constitutionalism of a an incipient area of freedom, security and justice. ${ }^{67}$

The project of thinking about contestation and deliberation in private international law is not merely urgent; it is also, intriguingly, to a large extent new. Contemporary private international law still very much rests on foundations lain in the early Postwar period. In this modern foundational period, much of its principles and doctrines were made subservient to one single, overriding goal: that of limiting the power of the state. ${ }^{68}$ But whereas in one of the other main legal constructions of that period - the European integration process - some form of recalibration has at least been forcefully debated under the guise of constitutional pluralism, no similar process of reflection has yet taken place within private international law. Conversations on the scope and content of a constitutionalism for the conflict of laws, then, to a large extent, are conversations still to be had.

This comparison between intellectual trajectories in private international law and in other areas of transnational legal ordering is also useful in revealing how we may in fact be witnessing some signs of a changing mood. The years since the outbreak of the global financial crisis have seen numerous attempts to reassert local authority over transnational domains. ${ }^{69}$ In areas like the fight against corruption or tax evasion, local polities, just like 1920s American state legislatures,

\footnotetext{
${ }^{67}$ These problems are especially visible whenever the EU legal sphere interacts with the outside world, and so itself acts at a 'local' level. The Brussels I Regulation - certainly until the recent 2012 'Recast' showed precious little 'environmental responsibilities' towards individuals not domiciled in an EU Member State, or to litigation pending in third-state courts, for example.

${ }^{68} \mathrm{My}$ colleague Jan Kleinheisterkamp and I explore the intellectual history of private international law in this period in a current project on the 'Postwar Paradigm in Private International Law'. Perhaps the clearest example is the $1958 \mathrm{New}$ York Arbitration Convention. On this type of historicity in the conflict of laws, see, e.g., Cavers, American Slavery and the Conflict of Laws, 71 Colum. L. Rev. 74 (1971).

69 See, e.g., the European and US provisions on reporting requirements for payments made to governments in the mining (and, in EU law: also forestry) sectors. For the EU, see European Parliament Legislative Resolution of 12 June 2013 on the proposal for a Directive of the European Parliament and of the Council amending Directive 2004/109/EC on the harmonization of transparency requirements in relation to information about issuers whose securities are admitted to trading on a regulated market and Commission Directive 2007/14/EC, especially Recital 7 and Article 6. For the US see s. 1504 of the Dodd Frank Act (s. 13q Securities Exchange Act 1934), and the implementing rule issued by the Securities and Exchange Commission on 22 August 2012 (Rule 13q-1).
} 
are rediscovering points of 'touchdown', as Robert Wai calls them, at which to regulate hazardous transnational activities. Without an understanding of private international law as a constitutional phenomenon - a phenomenon with the capacity to both constitute and limit both local and trans-local autonomy - such renewed assertions of public authority over transnational private legal relations will remain, in the familiar paradoxical mode that characterizes all constitutionalism, both unlikely to be successful, and, if realized, potentially dangerous. 